\title{
Optimasi Formula dan Uji Aktivitas Secara In Vitro Lotion O/W Ekstrak Etanolik Rimpang Temu Mangga (Curcuma Mangga Val. dan van Zijp) sebagai Tabir Surya
}

Formula Optimization and Activity Test In Vitro Lotion $O / W$ Ethanolic Extract
of Mangga Temperature (Curcuma Mangga Val. and Van Zijp) as Solar Tables

Mercy Arizona, A. Karim Zulkarnain*

Fakultas Farmasi UGM Yogyakarta

Corresponding author: A. Karim Zulkarnain: Email: akarimzk08@gmail.com

\begin{abstract}
ABSTRAK
Ekstrak temu mangga (Curcuma mangga Val.) memiliki aktivitas sebagai tabir surya secara spektrofotometri. Penelitian ini bertujuan untuk mengetahui formula optimum lotion $o / w$, sifat dan stabilitas fisik formula optimum lotion $o / w$, serta aktivitas tabir surya formula optimum lotion $o / w$ ekstrak temu mangga (Curcuma mangga Val.) secara spektrofotometri. Formula optimum diperoleh dengan metode Simplex Lattice Design (SLD). Respon yang digunakan untuk menentukan formula optimum adalah daya lekat dan viskositas. Stabilitas fisik lotion $o / w$ pada suhu ruang meliputi uji daya sebar, daya lekat, dan viskositas, serta uji freeze thaw cycling. Aktivitas tabir surya lotion $o / w$ ditentukan secara spektrofotometri untuk menentukan Sun Protecting Factor (SPF), \% transmisi eritema, dan \% transmisi pigmentasi. Data dianalisis dengan One Way ANOVA dan uji t. Hasil penelitian menunjukkan bahwa formula optimum lotion $o / w$ pada kombinasi $5 \%$ trietanolamin (TEA)-stearat dan $5 \%$ setil alkohol. Lotion o/w ekstrak temu mangga memiliki memiliki daya sebar $63,21 \pm 2,69 \mathrm{~cm}^{2}$, daya lekat 2,32 $\pm 0,15$ detik, dan viskositas sebesar 133,5 $\pm 8,05$ dPas. Hasil analisis statistika menunjukkan bahwa lotion $o / w$ smemiliki stabilitas yang baik. Lotion $o / w$ mempunyai aktivitas sebagai tabir surya pada konsentrasi lotion $o / w 12,5 \%$ yang ditunjukkan dengan nilai SPF sebesar 12,82 $\pm 0,16$ dan tidak efektif dalam perlindungan terhadap eritema dan pigmentasi.
\end{abstract}

Kata kunci: Curcuma mangga, lotion, SLD, tabir surya

\begin{abstract}
Intersection mango extract (Curcuma mango Val.) Has activity as a sunscreen by spectrophotometry. This study aims to determine the optimum formula lotion $\mathrm{o} / \mathrm{w}$, properties and physical stability of the optimum formula lotion $\mathrm{o} / \mathrm{w}$, and the activities of the optimum formula sunscreen lotion o/w Intersection mango extract (Curcuma mango Val.) by spectrophotometry. The optimum formula was obtained by the method Simplex Lattice Design (SLD). Responses are used to determine the optimum formula is the bonding strength and viscosity. Physical stability lotion o/w at room temperature include tests dispersive power, adhesion, and viscosity, as well as freeze thaw cycling test. Activities sunscreen lotion o/w determined by spectrophotometry to determine the Sun Protecting Factor (SPF),\% transmission erythema, and\% transmission pigmentation. Data were analyzed by One Way ANOVA and t test. The results showed that the optimum formula lotion o/w on a combination of 5\% triethanolamine (TEA) -stearat and 5\% cetyl alcohol. Lotion o/w intersection mango extracts have had the scatter $63.21 \pm 2.69 \mathrm{~cm}^{2}$, the stickiness of $2.32 \pm 0.15$ seconds, and the viscosity of $133.5 \pm 8.05 \mathrm{dPas}$. Results of statistical analysis
\end{abstract}


showed that the lotion $\mathrm{o} / \mathrm{w}$ has good stability. Lotion $\mathrm{o} / \mathrm{w}$ has activity as a sunscreen lotion at concentrations o/w $12.5 \%$ are indicated with an SPF value of $12.82 \pm 0.16$ and ineffective in the protection against erythema and pigmentation.

Keyword: Curcuma mango, lotion, SLD, sunscreen

\section{PENDAHULUAN}

Pemaparan sinar matahari (sinar UV) yang berlebihan dapat menyebabkan eritema, hiperpigmentasi, bahkan sampai menyebabkan kanker kulit. Sinar UV yang paling berpotensi menyebabkan eritema adalah sinar UV B (290nm-320nm), dan yang menyebabkan pigmentasi adalah sinar UV A (320nm-400nm). Sedangkan sinar UV C (100nm-290nm) bersifat karsinogenik, namun sinar tersebut dapat disaring oleh lapisan ozon sehingga tidak sampai di permukaan bumi (Elmarzugi et al., 2013).

Adanya dampak negatif sinar matahari tersebut maka kita perlu menggunakan pelindung kulit tabir surya. Tabir surya akan menyerap sinar UV dan menghalangi penetrasi sinar UV ke lapisan epidermis (Elmarzugi et al., 2013). Yuliani (2010) menyebutkan bahwa ekstrak etanolik Curcuma mangga Val. memiliki aktivitas sebagai tabir surya. Senyawa yang diduga berpotensi sebagai tabir surya adalah kurkumin yang mampu menyerap sinar UV A dan UV B.

Berdasarkan dampak negatif dari paparan sinar matahari dan kandungan temu mangga yang berpotensi sebagai agen tabir surya, maka perlu dikembangkan sediaan kosmetika yang berfungsi sebagai tabir surya. Umumnya sediaan tabir surya berupa sediaan lotion (Elmarzugi et al., 2013) dan termasuk dalam salah satu jenis skin care cosmetics. Lotion merupakan salah satu jenis produk kosmetik yang berupa emulsi minyak dalam air $(o / w)$ yang dapat membersihkan dan menjaga kesehatan kulit. Pada dasarnya skin care cosmetics dapat melindungi kulit radiasi ultraviolet dan membersihkan kulit sehingga tetap indah dan sehat (Mitsui, 1997).
Lotion $o / w$ tabir surya umumnya berbentuk emulsi dengan substantivitas yang bagus untuk dapat mengoptimalkan aktivitas sun protection factor (SPF) (Shaath, 2005). Untuk menjaga kestabilan dan substantivitas lotion diperlukan pengaturan jumlah bahan pengental yang digunakan yaitu setil alkohol. Untuk mendapatkan emulsi yang stabil maka diperlukan pengaturan terhadap emulgator yang digunakan yaitu trietanolaminstearat. Pengaturan emulgator perlu dilakukan untuk menjamin stabilitas emulsi. Sehingga lotion yang dihasilkan dapat berfungsi secara optimal.

Temu mangga mengandung senyawa flavonoid, kurkumin, demetoksikurkumin, bisdemetoksikurkumin, asam galat, katekin, epikatekin, epigalokatekin, epigalokatekingalat, dan galokatekingalat (Setyaningrum et al., 2013; Abas et al., 2005; dan Pujimulyani, 2013). Ekstrak etanolik Curcuma mangga Val. mengandung kurkumin sebesar $(0,19 \pm 0,0131) \%$ (Sumarny et al., 2012) dan mengandung total flavonoid sebesar $(0,15 \pm 0,00) \mathrm{mg}$ Eq kuersetin/kg bk (Setyaningrum et al., 2013).

Paparan sinar matahari dapat dapat merugikan manusia berupa radiasi sinar UV yang tergantung pada waktu penyinaran, letak geografis, cuaca, dan lingkungan. Radiasi UV tidak dapat dirasakan dan dilihat, serta tidak bergantung pada suhu dan masih memiliki intensitas yang tinggi walaupun cuaca berawan (Anonim, 2003). Panjang gelombang sinar ultraviolet dapat dibagi menjadi 3 bagian: 1 . Ultraviolet $\mathrm{A}$ dengan panjang gelombang antara 320-400 nm, menginduksi kerusakan kulit, seperti pigmentasi tidak merata, peradangan 
Tabel I. Klasifikasi SPF (Murphy, 2005)

\begin{tabular}{cll}
\hline SPF & \multicolumn{1}{c}{ Kategori } & \multicolumn{1}{c}{ Level Proteksi } \\
\hline$\geq 30$ & Proteksi tinggi & Untuk kulit yang mudah mengalami sunburn \\
$12-29$ & Proteksi sedang & Untuk kulit yang kemungkinan mengalami sunburn -nya \\
& sedang
\end{tabular}

pada kulit, dan UVA lebih mudah menembus kaca jendela (Elmarzugi et al., 2013). 2 Ultraviolet $B$ panjang gelombang antara 290-320nm yang dapat menimbulkan sunburn. Sunburn merupakan eritema akut yang terjadi dalam hitungan jam dan mencapai maksimum kira-kira 1224 jam setelah paparan sinar UV B. Kerusakan DNA setelah radiasi UV B menghasilkan eritema (Arakane, 2016). 3. Ultraviolet $C$ dengan panjang gelombang di bawah 100-290 nm, bersifat paling karsinogenik, tetapi sebagian besar telah tersaring oleh lapisan ozon dalam atmosfer (Elmarzugi et al., 2013).

Menurut Tortora (2009), kulit terdiri dari 2 bagian utama yaitu: Epidermis dan dermis. Lapisan dermis terdiri dari jaringan kolagen dan serat elastis. Lapisan ini berperan dalam pengaturan elastisitas dan termoregulasi kulit dengan menyediakan nutrisi bagi kulit (Couturaud, 2009).

Lotion merupakan bentuk sediaan farmasi yang berupa larutan atau suspensi dan digunakan secara topikal (Jones, 2008). Lotion lebih disukai pemakai karena memiliki daya sebar dan estetika yang lebih baik (Levy, 2009). Selain itu, lotion bersifat lebih ringan, tidak berminyak, dan dapat memberikan efek dingin dengan segera saat dioleskan pada kulit. Sedangkan untuk sifat alirnya, lotion bersifat newtonian atau pseudoplastik (Buhse et al., 2005).

Untuk pemakaian kulit lotion merupakan sediaan yang dipilih dalam menghidrasi kulit. Sediaan lotion berbentuk emulsi yang terdiri dari humektan, emolien, dan occlusive agent yang ketiganya berfungsi untuk mengatur kelembapan kulit. Occlusive agent mengatur kelembapan kulit dengan menghambat secara fisik penguapan air dari dalam tubuh. Humektan mengatur kelembapan kulit dengan menarik air di sekelilingnya. Sedangkan emolien dapat menghambat penguapan air dari dalam tubuh, namun lebih efektif di dalam melembutkan kulit (Liverman, 2009).

Surfaktan memiliki sisi hidrofilik dan lipofilik dalam satu molekul. Berdasarkan bentuk ionisasinya, surfaktan diklasifikasikan menjadi 4 kelompok, yaitu anionik, kationik, nonionik, dan amfoterik (Iwata, 2013).

Surfaktan anionik memiliki kemampuan menyabun, emulsifikasi, dan permeabilitas dengan baik. Surfaktan jenis ini, dikelompokkan menjadi 4 grup yaitu grup hidrofilik, asam sulfonat, asam sulfat, asam karboksilat, dan fosfat (Iwata, 2013).

Tabir surya merupakan zat yang menghambat efek dari sinar matahari yang berbahaya. Tabir surya apabila digunakan sebagai lotion maka dapat mengurangi risiko kanker kulit, termasuk melanoma (Anonim, 2015).

\section{Evaluasi SPF secara in vitro}

Sun Protection Factor (SPF) merupakan rasio yang menggambarkan respon terhadap paparan sinar UV pada kulit yang diolesi tabir surya dan yang tidak diolesi tabir surya (Nash, 2006). Penentuan nilai SPF dapat ditentukan secara in vitro dan in vivo. Pengukuran SPF secara in vitro merupakan uji yang menirukan pengukuran SPF secara in vivo menggunakan energi transmisi yang menembus tabir surya. Pengukuran SPF secara in vitro bertujuan untuk memprediksi nilai SPF produk di laboratorium dengan menggunakan 
Tabel II. Kategori penilaian aktivitas tabir surya (Balsam, 1972)

\begin{tabular}{ccc}
\hline \multirow{2}{*}{ Kategori penilaian } & \multicolumn{2}{c}{ Rentang sinar UV yang ditransmisi } \\
\cline { 2 - 3 } & \% eritema & \% pigmentasi \\
\hline Sunblock & $<1$ & $3-40$ \\
Proteksi ekstra & $1-6$ & $42-86$ \\
Suntan standar & $6-12$ & $45-86$ \\
Fast tanning & $10-18$ & $45-86$ \\
\hline
\end{tabular}

spektrofotmeter. Apabila pengukuran SPF secara in vitro akurat, maka formulator dapat meminimalisir biaya yang digunakan dalam skrining formula baru untuk diuji selanjutnya. Apabila nilai SPF secara in vitro sesuai dengan nilai SPF secara in vivo, dapat diasumsikan bahwa hasil transmitasi pada pengukuran secara in vitro adalah benar (Stanfield, 2005).

Penentuan nilai SPF secara in vitro dilakukan dengan spektrofotometer UV-Vis. Salah satu metode yang dapat digunakan adalah metode Mansur. Dalam metode Mansur, pembacaan absorbansi larutan sampel dilakukan pada panjang gelombang 290-320 nm dengan rentang $5 \mathrm{~nm}$ dan dibaca sebanyak 3 kali pada titik yang sama.

\section{Evaluasi nilai \% TE dan \% TP}

Prosen (\%) TE dapat ditentukan dengan cara spektrofotometri yaitu dengan mengukur absorbansi larutan sampel pada rentang panjang gelombang yang menimbulkan eritema pada panjang gelombang 292,5-337,5 nm. Sedangkan untuk \% TP dilakukan pembacaan absorbansi larutan sampel pada panjang gelombang yang menimbulkan pigmentasi, yaitu pada panjang gelombang 332,5-372,5 $\mathrm{nm}$. Pembacaan dilakukan dengan interval $5 \mathrm{~nm}$. Dari nilai serapan yang didapat, dihitung nilai serapan untuk $1 \mathrm{~g} / \mathrm{L} / \mathrm{cm}$ dan $\mathrm{T} \% 1 \mathrm{~g} / \mathrm{L}$ dengan rumus $\mathrm{A}=-\log \mathrm{T}$. Nilai transmisi eritema dihitung dengan mengalikan nilai transmisi (T) dengan faktor efektivitas eritema ( $\mathrm{Fe}$ ) pada panjang gelombang 292,5-337,5 nm. Sedangkan nilai transmisi pigmentasi dihitung dengan mengalikan nilai transmisi (T) dengan faktor pigmentasi (Fp) pada panjang gelombang 332,5-372,5 nm (Cumpelik, 1972).

\section{METODOLOGI}

Alat yang digunakan adalah alat penyerbuk, penangas air (Yenaco $\left.{ }^{\circledR}\right)$, almari es (Panasonic ${ }^{\circledR}$ ), oven (Memmert ${ }^{\circledR}$ ), lempeng KLT, sinar UV 254nm dan 366nm, timbangan analitik (Adventurer Dhans ${ }^{\circledR}$ ), viskosimeter seri VT 04 (RION $\left.{ }^{\circledR}\right)$, Ultra Turrax T25 (Jenke \& Kunkel IKA ${ }^{\circledR}$ Labortechnik), stopwatch, kaca bulat berskala, alat uji daya lekat, spektrofotometri UV-Vis (Hitachi U-2900 ${ }^{\circledR}$ ), pH universal, dan mikrometer.

Bahan utama yang digunakan dalam penelitian ini adalah ekstrak kental etanolik temu mangga (Curcuma mangga Val.). Bahan yang dibutuhkan adalah etanol $70 \%$ dan 96\%, senyawa murni kurkuminoid, kloroform, setil alkohol (derajat farmasi), asam stearat, trietanolamin, gliserin, minyak mineral, propil paraben, metil paraben (semuanya derajat farmasi), dan akuades.

\section{Cara lerja \\ Penetapan nilai SPF ekstrak}

Ekstrak etanol Curcuma mangga Val. diambil sebanyak 0,200 $\mathrm{mL} ; 0,225 \mathrm{~mL}$; $0,250 \mathrm{~mL} ; 0,275 \mathrm{~mL}$ dan $0,300 \mathrm{~mL}$ dengan replikasi masing-masing sebanyak tiga kali, kemudian diencerkan dengan etanol 96\% hingga $10 \mathrm{~mL}$. Data serapan diambil pada rentang panjang gelombang $290 \mathrm{~nm}$ sampai $320 \mathrm{~nm}$ pada tiap kenaikan $5 \mathrm{~nm}$ dan dilakukan tiga kali pengulangan. Selanjutnya dihitung nilai SPF dengan persamaan Mansur, yaitu : 
Tabel III. Variasi komposisi campuran untuk menentukan formula optimum

\begin{tabular}{lcccccccc}
\hline \multicolumn{1}{c}{ Bahan } & F1 & F2 & F3 & F4 & F5 & F6 & F7 & F8 \\
\hline Ekstrak rimpang temu & 0,135 & 0,135 & 0,135 & 0,135 & 0,135 & 0,135 & 0,135 & 0,135 \\
mangga & 3 & 4 & 3 & 5 & 3,5 & 4 & 5 & 4,5 \\
Setil alkohol & 1,17 & 1 & 1,17 & 0,83 & 1,08 & 1 & 0,83 & 0,92 \\
Trietanolamin & 2,5 & 2,5 & 2,5 & 2,5 & 2,5 & 2,5 & 2,5 & 2,5 \\
Gliserin & 1,5 & 1,5 & 1,5 & 1,5 & 1,5 & 1,5 & 1,5 & 1,5 \\
Lanolin & 5,83 & 5 & 5,83 & 4,17 & 5,42 & 5 & 4,17 & 4,58 \\
Asam stearat & 3 & 3 & 3 & 3 & 3 & 3 & 3 & 3 \\
Minyak mineral & 0,05 & 0,05 & 0,05 & 0,05 & 0,05 & 0,05 & 0,05 & 0,05 \\
Propil paraben & 0,10 & 0,10 & 0,10 & 0,10 & 0,10 & 0,10 & 0,10 & 0,10 \\
Metil paraben & 100 & 100 & 100 & 100 & 100 & 100 & 100 & 100 \\
Aquades ad (mL) & & & & & & & &
\end{tabular}

$\mathrm{SPF}=\mathrm{CF} \times \sum_{290}^{320} \mathrm{EE}(\lambda) \times \mathrm{I}(\lambda) \times A b s(\lambda)$

(Mansur et. al., 1986)

Variasi Formula Lotion $o / w$ yang lakukan optimasi (Tabel III).

\section{Pembuatan Lotion o/w}

Fase minyak dan fase air masingmasing dicampur dan dipanaskan pada suhu $65^{\circ}-75^{\circ} \mathrm{C}$. Fase air ditambahkan pada fase minyak sambil diaduk dengan menggunakan ultra turrax T25 dan sambil terus dilakukan pengadukan. Selanjutnya ditambakhkan ekstrak yang sudah dilarutkan dalam sebagian fase air dan diaduk sampai homogen.

\section{Uji stabilitas sifat fisik}

Berupa uji viskositas, Uji daya lekat, Uji daya sebar, Uji $\mathrm{pH}$, Uji volume pemisahan dipercepat dengan metode cycling test yaitu penyimpanan sediaan pada suhu ekstrim $8^{\circ} \mathrm{C}$ dan $45^{\circ} \mathrm{C}$ (Suwandi et al., 2012; Niazi, 2004). Uji dilakukan dengan pemberian kondisi stress pada suhu $45^{\circ} \mathrm{C}$ dan $8^{\circ} \mathrm{C}$ secara bergantian selama 5 siklus ( 1 siklus $=24$ jam pada $45^{\circ} \mathrm{C}$ dan 24 jam pada $8^{\circ} \mathrm{C}$ ). Volume pemisahan dapat dihitung dengan menggunakan rumus pada persamaan dari (Mollet \& Grubenmann, 2001).

$$
\begin{gathered}
\frac{H t}{H o}=\frac{V t}{V o}=\frac{L \times H t}{L \times H o} \ldots \ldots \ldots \ldots . . . . . . \\
\text { ( Mollet \& Grubenmann, 2001) }
\end{gathered}
$$

Keterangan: $\mathrm{F}$ : Rasio volume pemisahan; $\mathrm{Ht}$ : Tinggi emulsi pada waktu t; Ho : Tinggi emulsi mula-mula; Vt : Volume emulsi pada waktu t; Vo : Volume emulsi mula-mula; L : Luas penampang wadah.

Pengukuran nilai SPF Lotion $o / w$ dan Basis dengan aplikasi persamaan Mansur.

$$
\mathrm{SPF}=\mathrm{CF} \times \sum_{290}^{320} \mathrm{EE}(\lambda) \times \mathrm{I} \times \operatorname{Abs}(\lambda)
$$

Keterangan: CF : Correction Factor (10); EE $(\lambda)$ : Efek eritemogenik dari radiasi pada panjang gelombang $\lambda$; Abs $(\lambda)$ : Absorbansi pada panjang gelombang $\lambda$.

Penetapan nilai \% Transmisi Eritema dan Pigmentasi Lotion o $w$ dan Basis pada rentang panjang gelombang dari 292,5$372,5 \mathrm{~nm} . \%$ Te dan \%Tp dihitung dengan rumus:

$$
\begin{aligned}
& \% \mathrm{Te}=\frac{\Sigma E e}{\sum F e}=\frac{\sum(\mathrm{T} \times \mathrm{Fe})}{\sum F e} \\
& \% T p=\frac{\sum E p}{\Sigma F p}=\frac{\sum(\mathrm{T} \times \mathrm{F} p)}{\Sigma F p}
\end{aligned}
$$

Keterangan:\% Te : Persentase transmisi 
eritema; \% Tp : Persentase transmisi pigmentasi; Ee : Energi eritema; Ep : Energi pigmentasi; Fe : Faktor kefektifan eritema; Fp : Faktor keefektifan pigmentasi.

\section{HASIL DAN PEMBAHASAN}

Ekstrak temu mangga dibuat secara maserasi dengan etanol 70\%. Ekstrak yang diperoleh memiliki warna coklat tua, berbentuk semipadat dan kental, berbau khas, susut pengeringan sebesar $17,27 \pm 0,55 \%$, dan rendemen $4,52 \%$.

\section{Penentuan formula optimum}

Penentuan formula optimum dilakukan dengan menggunakan software Design Expert ${ }^{\circledR}$. Hasil uji daya sebar, daya lekat, dan viskositas lotion dari ke-8 formula digunakan sebagai bahan analisis untuk menentukan formula optimum. Respon yang digunakan sebagai dasar penentuan formula optimum adalah respon yang menghasilkan model yang signifikan dan lack of fit yang tidak signifikan.

\section{Viskositas}

Hasil uji viskositas dari semua formula dianalisis untuk mendapatkan komposisi setil alkohol dan TEA-stearat untuk menghasilkan viskositas yang optimum. Berdasarkan hasil analisis statistik, model yang disarankan adalah linear dan signifikan, serta lack of fit yang dihasilkan berbeda tidak signifikan. Sehingga viskositas dijadikan dasar dalam penentuan formula optimum.

Persamaan SLD respon viskositas adalah sebagai berikut:

$$
Y=142,86(A)+120,64(B)
$$

Keterangan: Y : viskositas lotion; A : komponen setil alkohol; B : komponen TEAstearat.

Persamaan respon viskositas tersebut menunjuukan bahwa viskositas lotion dipengaruhi oleh setil alkohol dan TEA-stearat. Akan tetapi, setil alkohol lebih berpengaruh dalam peingkatan viskositas lotion. Hal ini ditunjukkan oleh nilai komponen setil alkohol yang lebih besar daripada komponen TEA-stearat dalam persamaan respon viskositas.

Daya lekat: Hasil uji daya lekat dari semua formula dianalisis menggunakan software Design Expert ${ }^{\circledR} 9.0$ trial untuk mendapatkan komposisi setil alkohol dan TEA-stearat untuk menghasilkan daya lekat yang optimum. Berdasarkan hasil analisis statistik, model yang disarankan adalah linear dan signifikan, serta lack of fit yang dihasilkan berbeda tidak signifikan. Sehingga daya lekat digunakan sebagai dasar dalam penentuan formula optimum.

Persamaan Simplex Lattice Design respon daya lekat adalah sebagai berikut:

$$
\mathrm{Y}=2,31(\mathrm{~A})+1,71(\mathrm{~B})
$$

Keterangan: Y : daya lekat lotion; A : komponen setil alkohol; B : komponen TEAstearat.

Persamaan respon daya lekat tersebut menunjukkan bahwa daya lekat lotion dipengaruhi oleh setil alkohol dan TEA-stearat. Akan tetapi, setil alkohol lebih berpengaruh dalam daya lekat lotion karena nilai komponen setil alkohol yang lebih besar daripada komponen TEA-stearat dalam persamaan tersebut.

\section{Daya sebar}

Hasil uji daya sebar dari semua formula dianalisis menggunakan software Design Expert ${ }^{\circledR} 9.0$ untuk mendapatkan komposisi setil alkohol dan TEA-stearat untuk menghasilkan daya sebar yang optimum. Berdasarkan hasil analisis statistik, model yang disarankan adalah linier dan tidak signifikan, serta memiliki lack of fit yang berbeda tidak signifikan. Sehingga respon daya sebar tidak dapat digunakan sebagai dasar dalam penentuan formula optimum.

Persamaan Simplex Lattice Design respon daya sebar adalah sebagai berikut:

$$
Y=63,99(A)+54,09(B)
$$


Tabel IV. Nilai prediksi respon formula optimum

\begin{tabular}{cc}
\hline Respon & Nilai Prediksi \\
\hline Viskositas & 142,86 \\
Daya lekat & 2,31 \\
\hline
\end{tabular}

Tabel V. Formula optimum lotion

\begin{tabular}{cc}
\hline Respon & Nilai Prediksi \\
\hline Setil alkohol & 5 \\
Lanolin & 1,5 \\
Asam stearat & 4,17 \\
Minyak mineral & 3 \\
Propil paraben & 0,05 \\
Gliserin & 2,5 \\
Trietanolamin & 0,83 \\
Metil paraben & 0,1 \\
Ekstrak & 0,135 \\
Aquades & Ad 100 \\
\hline
\end{tabular}

Keterangan: Y : daya sebar lotionI; A : komponen setil alkohol; B : komponen TEAstearat

Persamaan respon daya sebar tersebut menunjukkan bahwa daya sebar lotion dipengaruhi oleh setil alkohol dan TEA-stearat. Akan tetapi, setil alkohol lebih berpengaruh dalam daya sebar lotion karena nilai komponen setil alkohol yang lebih besar daripada komponen TEAstearat dalam persamaan tersebut.

\section{Formula optimum lotion}

Respon viskositas dipilih maximize dengan mempertimbangkan bahwa semakin tinggi viskositas maka akan semakin stabil sediaan itu. Viskositas yang terlalu rendah akan memudahkan fase internal (fase minyak) untuk bergerak keluar dari medium dispers. Hal ini menyebabkan sistem dispersi yang tidak stabil.

Respon daya lekat dipilih in range dengan mempertimbangkan bahwa daya lekat yang dipilih berada pada rentang yang diinginkan. Dalam kegunaannya sebagai sunscreen maka daya lekat berkaitan dengan substantivitas atau sifat water resistance lotion. Apabila daya lekat terlalu rendah maka substantivitas dari lotion akan semakin berkurang, sehingga tidak dapat memberikan perlindungan yang optimal terhadap kulit. Namun apabila daya lekat terlalu tinggi maka akan menurunkan kenyamanan saat digunakan dan luas permukaan kontak. Selain itu, daya lekat yang terlalu tinggi akan menghambat fungsi-fungsi kulit secara fisiologis, seperti menghambat pernafasan kulit (Voigt, 1995).

Formula optimum ditentukan dengan nilai desirability tertentu. Nilai desirability memiliki rentang 0-1. Semakin tinggi nilai desirability, maka formula optimum semakin sesuai dengan target respon yang diharapkan. Hasil prediksi software Design Expert $^{\circledR} \quad 9.0$ trial memberikan nilai desirability 0,964 untuk formula optimum dengan konsentrasi setil alkohol 5\% dan TEA-stearat 5\%. Selain itu, dihasilkan pula nilai prediksi untuk sifat fisik lotion.

Nilai prediksi masing-masing respon (Tabel IV) dan Formula optimum yang dihasilkan (Tabel V).

\section{Verifikasi respon prediksi dan aktual}

Tujuan dilakukan verifikasi adalah untuk mengetahui validitas nilai prediksi respon sifat fisik lotion dari formula optimum. Formula optimum yang 
Tabel VI. Hasil uji sifat fisik formula optimum

\begin{tabular}{cc}
\hline Respon & Nilai Aktual \\
\hline Viskositas & $133,5 \pm 8,05 \mathrm{dPas}$ \\
Daya lekat & $2,32 \pm 0,15 \mathrm{detik}$ \\
Daya sebar & $63,21 \pm 2,69 \mathrm{~cm}^{2}$ \\
\hline
\end{tabular}

Tabel VII. Hasil uji t satu sampel respon prediksi dan respon aktual

\begin{tabular}{ccccc}
\hline Respon & $\begin{array}{c}\text { Nilai } \\
\text { Prediksi }\end{array}$ & Nilai Aktual & Signifikansi & Interpretasi \\
\hline Viskositas & 142,861 & $133,5 \pm 8,05 \mathrm{dPas}$ & 0,181 & Berbeda tidak bermakna \\
Daya lekat & 2,3141 & $2,32 \pm 0,15 \mathrm{detik}$ & 0,933 & Berbeda tidak bermakna \\
\hline
\end{tabular}

Tabel VIII. Hasil uji daya sebar lotion dan basis selama 4 minggu

\begin{tabular}{ccc}
\hline \multirow{2}{*}{ Minggu ke- } & \multicolumn{2}{c}{ Daya sebar $\left.\mathbf{( c m}^{2}\right)$} \\
\cline { 2 - 3 } & Lotion & Basis \\
\hline 0 & $56,27 \pm 0,88$ & $43,28 \pm 2,00$ \\
1 & $58,35 \pm 2,71$ & $45,58 \pm 3,51$ \\
2 & $60,83 \pm 4,30$ & $46,62 \pm 6,10$ \\
3 & $60,93 \pm 2,39$ & $42,94 \pm 3,10$ \\
4 & $57,54 \pm 6,10$ & $47,22 \pm 3,55$ \\
\hline
\end{tabular}

didapatkan dari software Design Expert ${ }^{\circledR} 9.0$ trial dibuat sediaan lotion dengan cara yang sama seperti pembuatan ke-8 formula sebelumnya. Formula optimum diuji sifat fisiknya yang meliputi uji viskositas, daya sebar, dan daya lekat.

Selanjutnya dianalisis nilai prediksi dan nilai aktual untuk data viskoritas dan daya lekat secara statistika. Hasil analisis statistika dapat dilihat pada tabel di bawah ini.

\section{Stabilitas fisik formula optimum}

Lotion yang dihasilkan diuji stabilitas fisiknya meliputi uji stabilitas pada suhu ruang yang meliputi viskositas, daya sebar, dan daya lekat. Serta dilakukan uji stabilitas dipercepat dengan metode cycling test. Selanjutnya dilakukan analisis statistika dengan menggunakan one way ANOVA untuk data terdistribusi normal dan Kruskal Wallis untuk data tidak terdistribusi normal.

Daya sebar, pengujian daya sebar dilakukan selama 4 minggu. Hal ini bertujuan untuk mengetahui pengaruh peenyimpanan terhadap kemampuan daya sebar lotion. Hasil uji daya sebar lotion dapat ditunjukkan dalam tabel dan grafik di bawah. Hasil uji daya sebar menunjukkan bahwa semakin lama waktu penyimpanan maka daya sebar lotion dan basis relatif stabil. Selanjutnya data dianalisis dengan uji statistik. Pada formula optimum lotion memiliki signifikansi $0,435(\mathrm{p}>0,05)$ dan basis memiliki signifikansi $0,652(p>0,05)$ yang artinya data terdistribusi normal Sehingga untuk mengetahui kebermaknaan perbedaan dari daya sebar lotion dan basis selama penyimpanan 4 minggu, maka dilakukan uji one way ANOVA dengan taraf kepercayaan 95\%.

Daya lekat, pengujian daya lekat dilakukan selama 4 minggu. Hal ini dilakukan untuk mengetahui pengaruh lama penyimpanan terhadap kemampuan daya lekat lotion dan basis. Hasil pengujian menunjukkan bahwa semakin lama penyimpanan pada suhu ruang lotion maka daya lekatnya fluktuatif dan cenderung 
Tabel IX. Hasil analisis statistika uji t daya sebar stabilitas fisik lotion dan basis

\begin{tabular}{ccc}
\hline Formula & Signifikansi & Interpretasi \\
\hline Lotion & 0,497 & Berbeda tidak bermakna \\
Basis & 0,583 & Berbeda tidak bermakna \\
\hline
\end{tabular}

Tabel X. Hasil uji daya lekat lotion dan basis selama 4 minggu

\begin{tabular}{ccc}
\hline \multirow{2}{*}{ Minggu ke- } & \multicolumn{2}{c}{ Daya lekat (detik) } \\
\cline { 2 - 3 } & Lotion & Basis \\
\hline 0 & $2,33 \pm 0,16$ & $2,18 \pm 0,11$ \\
2 & $2,37 \pm 0,16$ & $2,47 \pm 0,33$ \\
3 & $2,47 \pm 0,09$ & $2,05 \pm 0,14$ \\
4 & $2,25 \pm 0,15$ & $1,84 \pm 0,22$ \\
& $2,45 \pm 0,13$ & $2,29 \pm 0,17$ \\
\hline
\end{tabular}

Tabel XI. Hasil analisis statistika uji t daya lekat stabilitas fisik lotion dan basis

\begin{tabular}{ccc}
\hline Formula & Signifikansi & Interpretasi \\
\hline Lotion & 0,537 & Berbeda tidak bermakna \\
Basis & 0,037 & Berbeda bermakna \\
\hline
\end{tabular}

Tabel XII. Hasil uji viskositas lotion dan basis selama 4 minggu

\begin{tabular}{ccc}
\hline \multirow{2}{*}{ Minggu ke- } & \multicolumn{2}{c}{ Viskositas (dPas) } \\
\cline { 2 - 3 } & Lotion & Basis \\
\hline 0 & $133,17 \pm 9,26$ & $151 \pm 2,11$ \\
1 & $141,83 \pm 5,69$ & $143 \pm 4,83$ \\
2 & $135,67 \pm 11,73$ & $151 \pm 2,11$ \\
4 & $142,17 \pm 3,25$ & $152,5 \pm 3,54$ \\
4 & $133,67 \pm 15,22$ & $154,5 \pm 3,69$ \\
\hline
\end{tabular}

stabil. Sedangkan untuk basis semakin lama penyimpanan pada suhu ruang maka daya lekatnya fluktuatif dan cenderung tidak stabil. Selanjutnya data dianalisis dengan uji statistik. Pada formula optimum lotion memiliki signifikansi $0,824(p>0,05)$ dan basis memiliki signifikansi $0,408(p>0,05)$ yang artinya data daya lekat lotion dan basis terdistribusi normal. Sehingga untuk mengetahui kebermaknaan perbedaan dari daya lekat lotion dan basis selama 4 minggu, maka dilakukan uji one way ANOVA dengan taraf kepercayaan 95\%.

Viskositas, pengujian viskositas dilakukan selama 4 minggu. Hal ini dilakukan untuk mengetahui pengaruh lama penyimpanan terhadap kemampuan viskositas lotion dan basis. Hasil pengujian menunjukkan bahwa semakin lama penyimpanan lotion maka viskositas menunjukkan hasil yang cenderung stabil. Sedangkan semakin lama penyimpanan pada suhu ruang basis maka viskositas menunjukkan hasil yang fluktuatif dan cenderung tidak stabil. Selanjutnya data dianalisis dengan uji statistik. Pada formula optimum lotion memiliki signifikansi 0,210 ( $p>0,05)$ yang artinya data terdistribusi normal. Sedangkan untuk basis memiliki signifikansi $0,000(\mathrm{p}<0,05)$ yang artinya data terdistribusi tidak normal. Sehingga untuk mengetahui kebermaknaan perbedaan dari viskositas lotion selama 4 minggu, maka dilakukan uji one way ANOVA dengan taraf kepercayaan 95\% unuk lotion dan uji Kruskal Wallis untuk basis. 
Tabel XIII. Hasil an alisis statistika uji t daya sebar stabilitas fisik lotion dan basis

\begin{tabular}{lcl}
\hline Formula & Signifikansi & \multicolumn{1}{c}{ Interpretasi } \\
\hline Lotion & 0,537 & Berbeda tidak bermakna \\
Basis & 0,000 & Berbeda bermakna \\
\hline
\end{tabular}

Tabel XIV. Hasil uji SPF ekstrak temu mangga

\begin{tabular}{ccc}
\hline Konsentrasi (v/v) & SPF & Kategori \\
\hline $2 \%$ & $19,069 \pm 0,419$ & Proteksi sedang \\
$2,25 \%$ & $21,648 \pm 0,231$ & Proteksi sedang \\
$2,50 \%$ & $23,429 \pm 0,608$ & Proteksi sedang \\
$2,75 \%$ & $24,255 \pm 0,586$ & Proteksi sedang \\
$3 \%$ & $28,653 \pm 0,147$ & Proteksi sedang \\
\hline
\end{tabular}

Uji stabilitas dipercepat, uji stabilitas dipercepat dilakukan dengan menggunakan metode cycling test yang berfungsi untuk mengetahui kestabilan sediaan selama distribusi dan penyimpanan dengan perubahan suhu secara ekstrem (Niazi, 2004). Dalam cycling test sediaan diperlakukan dalam suhu yang berbeda dalam satu siklus. Masing-masing siklus terdiri dari 24 jam pada temperatur $8^{\circ} \mathrm{C}$ dan 24 jam pada suhu $45^{\circ} \mathrm{C}$ (Suwandi et al., 2012; Niazi, 2004). Cycling test digunakan untuk penentuan shelf-life suatu produk dalam industri (Anonim, 2005). Dalam uji dipercepat dapat diamati ketidakstabilan emulsi melalui perubahan fisiknya, seperti terjadinya pemisahan fase. Hasil uji Cycling test lotion dan basis menunjukkan bahwa selama 5 siklus perlakuan, semua formula optimum tidak mengalami pemisahan dan tidak mengalami perubahan warna sediaan. Kestabilan emulsi juga dapat dilihat dari rasio volume pemisahan pada ke-5 siklus. Hasil perhitungan rasio volume pemisahan menunjukkan bahwa nilai $\mathrm{F}=1$ yang berarti emulsi yang terbentuk berada dalam kesetimbangan flokulasi dan semakin baik stabilitas emulsi tersebut (Mollet dan Grubenmann, 2001).

\section{Penentuan aktivitas tabir surya}

Penentuan aktivitas tabir surya meliputi penentuan nilai SPF ekstrak dan lotion dengan metode Mansur. Selanjutnya dilakukan juga penentuan nilai $\%$ transmisi eritema dan pigmentasi (TeTp) pada sediaan lotion.

\section{Penentuan nilai SPF ekstrak}

Hasil uji menunjukkan bahwa semakin tinggi konsentrasi ekstrak maka semakin tinggi pula nilai SPF yang didapatkan. Dari tabel di atas adapat diketahui bahwa konsentrasi 3\% dapat memberikan nilai SPF sebesar 28,65. Hal ini menunjukkan bahwa ekstrak pada konsentrasi tersebut dapat memberikan proteksi sedang terhadap sunburn dan tanning.

\section{Penentuan nilai SPF lotion}

Berdasarkan hasil uji SPF dapat diketahui bahwa semakin tinggi konsentrasi lotion dan basis maka semakin tinggi pula nilai SPF yang didapatkan. Selain itu, basis memiliki SPF yang lebih kecil daripada lotion dengan konsentrasi yang sama. Bahkan, basis tidak memiliki aktivitas sebagai tabir surya pada konsentrasi 2,5\%; 5\%; dan 7,5\%. Tingkat proteksi berdasarkan nilai SPF yang dihasilkan menunjukkan bahwa lotion ekstrak temu mangga memiliki aktivitas sebagai tabir surya yang dapat memberikan proteksi sedang pada konsentrasi $12,5 \%$. Hal ini menunjukkan bahwa ekstrak dalam sediaan lotion tetap memiliki aktivitas sebagai tabir surya. Akan tetapi tidak sebesar seperti sebelum diformulasi. Hal ini dimungkinkan karena bahan-bahan yang digunakan dalam 
Tabel XV. Hasil uji SPF lotion

\begin{tabular}{ccc}
\hline Konsentrasi & SPF lotion & Kategori \\
\hline $2,5 \%$ & $2,508 \pm 0,233$ & Proteksi minimal \\
$5 \%$ & $3,761 \pm 0,328$ & Proteksi minimal \\
$7,5 \%$ & $5,081 \pm 0,388$ & Proteksi minimal \\
$10 \%$ & $6,656 \pm 0,347$ & Proteksi minimal \\
$12,5 \%$ & $12,817 \pm 0,161$ & Proteksi sedang \\
\hline
\end{tabular}

Tabel XVI. Hasil uji SPF basis

\begin{tabular}{ccl}
\hline Konsentrasi & SPF basis & Kategori \\
\hline $2,5 \%$ & $1,536 \pm 0,244$ & Not a sunscreen \\
$5 \%$ & $1,701 \pm 0,225$ & Not a sunscreen \\
$7,5 \%$ & $1,969 \pm 0,211$ & Not a sunscreen \\
$10 \%$ & $2,354 \pm 0,118$ & Proteksi minimal \\
$12,5 \%$ & $2,854 \pm 0,382$ & Proteksi minimal \\
\hline
\end{tabular}

Tabel XVII. Hasil uji \%TeTp lotion

\begin{tabular}{ccc}
\hline Konsentrasi & \%Te & \%Tp \\
\hline $2,5 \%$ & $97,619 \pm 0,693$ & $98,699 \pm 0,216$ \\
$5 \%$ & $98,439 \pm 0,203$ & $99,113 \pm 0,139$ \\
$7,5 \%$ & $98,281 \pm 0,071$ & $98,893 \pm 0,068$ \\
$10 \%$ & $98,227 \pm 0,178$ & $98,791 \pm 0,186$ \\
$12,5 \%$ & $97,726 \pm 0,016$ & $98,226 \pm 0,084$ \\
\hline
\end{tabular}

Tabel XVIII. Hasil uji \%TeTp basis

\begin{tabular}{ccc}
\hline Konsentrasi & \%Te & \%Tp \\
\hline $2,5 \%$ & $1,002 \pm 0,001$ & $1,004 \pm 0,003$ \\
$5 \%$ & $1,004 \pm 0,001$ & $1,004 \pm 0,001$ \\
$7,5 \%$ & $1,003 \pm 0,001$ & $1,002 \pm 0,001$ \\
$10 \%$ & $1,003 \pm 0,001$ & $1,002 \pm 0,000$ \\
$12,5 \%$ & $1,003 \pm 0,001$ & $1,002 \pm 0,000$ \\
\hline
\end{tabular}

formulasi telah menutupi aktivitas ekstrak sebagai tabir surya. Selain itu, nilai SPF ekstrak dan lotion tidak bisa diperbandingkan karena keduanya memiliki perlakuan yang berbeda dalam penentuan nilai SPF. Sehingga hanya bisa diketahui apakah ekstrak dalam formulasi masih memiiki aktivitas sebagai tabir surya atau tidak.

\section{Penentuan nilai \% transmisi eritema dan pigmentasi}

Berdasarkan hasil uji transmitasi eritema lotion, dapat diketahui bahwa lotion tidak memiliki perlindungan terhadap eritema karena memiliki \% transmitasi eritema $>18$. Sedangkan untuk transmitasi pigmentasi lotion, dapat diketahui bahwa lotion tidak dapat berfungsi sebagai pelindung tabir surya karena memiliki nilai $\%$ pigmentasi $>86$.

Berdasarkan hasil uji transmitasi eritema basis menunjukkan bahwa basis memiliki perlindungan ekstra terhadap eritema karena memiliki \% transmitasi eritema 1-6. Sedangkan untuk hasil \% transmitasi pigmentasi menunjukkan bahwa basis tidak dapat berfungsi sebagai pelindung terhadap pigmentasi karena memiliki \%pigmentasi $<3$. 
Berdasarkan hasil uji transmitasi eriema dan pigmentasi pada lotion dan basis, dapat diketahui bahwa keduanya tidak memiliki aktivitas menghambat transmisi pigmentasi. Akan tetapi basis memiliki aktivitas sebagai sunblock UV B dan lotion tidak memiliki aktivitas menghambat transmisi UV B.

\section{KESIMPULAN}

Kombinasi 5\% TEA-stearat dan 5\% setil alkohol dalam formula formula lotion $o / w$ ekstrak etanolik rimpang kunir mangga (Curcuma mangga Val.) dapat menghasilkan formula optimum, formula optimum lotion $o / w$ ekstrak etanolik rimpang kunir mangga (Curcuma mangga Val.) memiliki daya sebar $(63,21 \pm 2,69) \mathrm{cm}^{2}$, daya lekat $(2,32 \pm 0,15)$ detik, dan viskositas sebesar $(133,5 \pm 8,05)$ dPas, formula optimum lotion $o / w$ ekstrak etanolik rimpang kunir mangga (Curcuma mangga Val.) memiliki sifat fisik yang stabil selama 4 minggu penyimpanan di suhu ruang dan tidak menunjukkan adanya pemisahan selama 5 siklus pada uji stabilitas dipercepat dan Lotion $o / w$ ekstrak etanolik Curcuma mangga Val. memiliki aktivitas sebagai tabir surya pada konsentrasi lotion $12,5 \%$ dengan nilai SPF sebesar $12,8165 \pm 0,1606$ dan tidak efisien dalam perlindungan terhadap eritema dan pigmentasi.

\section{DAFTAR PUSTAKA}

Abas, F., Lajis, N.H., Shaari, K., Israf, D.A., Stanslas, J., Yusuf, U.K., \& Raof, S.M., 2005, A labdane diterpene glucoside from the rhizomes of Curcuma mangga, J. Nat. Prod.68, 1090-1093.

Anonim, 2003, Sun Protection: A Primary Teaching Resource, , 5, World Health Organization, Jenewa.

Anonim, 2005, ASEAN Guideline on Stability Study of Drug Product, 34, ASEAN, Filipina.

Anonim, 2015, Kamus Kesehatan, http://kamuskesehatan.com/arti/ta bir-surya/, Diakses tanggal 28 Februari 2015.

Arakane, K. N., 2016, UV Care., dalam R. J. Sivamani, Cosmeceuticals and Active Cosmetics Third Edition, 281-296, Boca Raton: CRC Press.

Balsam, M. S., 1972, Cosmetics: Science and Technology, 2nd Ed., Vols. 1-3 Interscience Publishers, Inc, New York. .

Buhse, L. Kolsinki, R., Westenberger, B., Wokovich, A., Spencer, J., Chen, C.W., Turujman, S., Gautam-Basak, M., Kang, G.J., Kibbe, A., Heintzelman, B., Wolfgang, E., 2005, Topical Drug Classification, International Journal of Pharmaceutics, 295, 101-112.

Couturaud, V., 2009, Biophysical Characteristics of the Skin in Relation to Race, Sex, Age, and Site, dalam A. P. Barel, Handbook of Cosmetics Science and Technology, 3rd edition, New York, Informa Healthcare.

Cumpelik, B., 1972, Analytical Procedures and Evaluation of Sunscreens, J.Soc. Cosmt. Chem., 23, 333-345.

Elmarzugi, N.A. Keleb, E. I. Mohamed, A.T. Issa, Y.S. Hamza, A.M. Layla, A.A. Salama, M. Bentaleb, A.M., 2013, The Relation between Sunscreen and Skin Pathochanges Mini Review, International Journal of Pharmaceutical Science Invention, 2(7), 43-52.

Iwata, H. S., 2013, Formulas, Ingredients and Production of Cosmetics: Technology of Skin and Hair Care Products in Japan, 39-67, Springer, Tokyo.

Jones, D., 2008, Pharmaceutical Dosage Form and Design, 86, Pharmaceutical Press, London.

Levy, S., 2009, skin Care Products: Artificial Tanning, dalam A. P. Barel, Handbook of Cosmetic Science and Technology, Third Edition, 339-344, Informa Healthcare New York.

Liverman, L. M., 2009, Mechanisms of Skin Hydration, dalam A. P. Barel, Handbook of Science and Technology, 
Third edition, 91-106, Informa Healthcare, New York.

Mansur, J.D.D, Breder, M.N.R., Mansur, M.C.D.A., Azulay, R.D., 1986, Determinac, ãodo fator de protec, ão solar por espectrofotometria, An. Bras. Dermatol, 61, 121-124 cit Costa, S.C.C., Detoni, C.B., Branco, C.R.C., Botura, M.B., Branco, A., 2015, In vitro photoprotective effects of Marcetia taxifolia ethanolic extract and its potential for sunscreen formulations, Brazilian Journal of Pharmacognosy, 25, 413-418.

Mitsui, T., 1997, New Cosmetic Science, 13, 319, 336, Elsevier Science B.V, Amsterdam.

Mollet, H \& Grubenmann, A., 2001, Formulation Technology : Emulsions, Suspensions, Solid Form, 261-262, Wiley-Vch, Toronto.

Murphy, E., 2005, The Final Monograph, dalam N. Shaath, Sunscreens Regulation and Commercial Development, Third edition, 96-114, Taylor \& Francis, Boca Raton.

Nash, J. T., 2006, Sunscreens, dalam Z. T. Draelos, Cosmetic Formulation of Skin Care Products, 135-151, Taylor \& Francis, New york.

Niazi, S.K., 2004, Handbook of Pharmaceutical Manufacturing Formulations, Semisolid Products, Voulme 4, CRC Press, Boca raton.

Pujimulyani, D. R., 2013, The Phenolic Substances and Antioxidant Activity of White Saffron (Curcuma mangga Val.) as affected by Blanching Methods, International Journal of Biological, Biomolecular, Agricultural, Food and Biotechnological Engineering, 7(10), 600-603.

Setyaningrum, A., Andriani., Yani, F., 2013, Potensi Temu Mangga (Curcuma mangga val.) Sebagai Minuman
Fungsional, Teknosains PanganI, 2, 27-33.

Shaath, N., 2005, The Chemistry of Ultraviolet Filters, dalam N. Shaath, Sunscreens Regulations and Commercial Development Third Edition, 227, Taylor \& Francis Group, New York.

Stanfield, J., 2005, In Vitro Techniques in Sunscreen Development, dalam N. Shaath, Sunscreens Regulations and Commercial Development, Third Edition, 854-880, Taylor \& Francis, Boca Raton.

Sumarny, R., Djamil, R., Indira, A., 2012, Kadar Kurkumin dan Potensi Antioksidan Ekstrak Etanol Rimpang Temu Putih (Curcuma zedoaria (Berg) Roscoe.), Temu Mangga (Curcuma mangga Val et Zyp.) dan Temulawak (Curcuma xanthorrhiza Roxb), Jurusan Farmasi Fakultas MIPA, Universitas Jenderal Achmad Yani, Cimahi.

Suwandi, A.O., Pramono, S., Mufrod, 2012, Pengaruh Konsentrasi Ekstrak Daun Kepel (Stelechocarpus burahol (BL) Hook f. \& Th.) Terhadap Aktivitas Antioksidan dan Sifat Fisik Sediaan Krim, Majalah Obat Tradisional, 17(2), 27-33.

Tortora, G. D., 2009, Principles of Anatomy and Physiology, Twelfth Edition. 148152, John Wilwy \& Sons, Inc, U.S.A.

Voigt, R., 1995, Buku Pelajaran Teknologi Farmasi, diterjemahkan oleh Soendani Noerono Soewandhi, 566,580, Gadjah Mada University Press, Yogyakarta.

Yuliani, H. S., 2010, Optimasi Kombinasi Campuran Sorbitol, Gliserol, dan Propilenglikol dalam Gel Sunscreen Ekstrak Etanol Curcuma mangga, Majalah Farmasi Indonesia, 2(2), 8389. 